\title{
$\dagger$ Electrupbilus wendeli gen.n., sp.n. - the first diving beetle recorded from Saxonian (Bitterfeld) Amber (Coleoptera: Dytiscidae: Laccophilinae)
}

\section{$\dagger$ Electrupbilus wendeli gen.n., sp.n. - первый вид плавунцов из Саксонского (Bitterfeld) янтаря (Coleoptera: Dytiscidae: Laccophilinae)}

\author{
M. Balke ${ }^{1}$, M. Toledo ${ }^{2}$, C. Gröhn ${ }^{3}$, I. Rappsilber ${ }^{4}$, L. Hendrich ${ }^{1}$ \\ М. Бальке ${ }^{1}$, М. Толедо ${ }^{2}$, К. Грё̈н ${ }^{3}$ И. Раппзильбер ${ }^{4}, \Lambda$. Хендрих $^{1}$
}

\footnotetext{
${ }^{1}$ Zoologische Staatssammlung, Münchhausenstrasse 21, D-81247 München, Germany. E-mail: balke.m@snsb.de

2 via Tosoni 20, 25128 Brescia, Italy.

${ }^{3}$ Bünebüttler Weg 7, 21509 Glinde, Germany.

${ }^{4}$ Landesamt für Geologie und Bergwesen Sachsen-Anhalt, Köthener Straße 38, 06118 Halle, Germany.
}

KEY WORDS. Dytiscidae, Laccophilinae, new genus, new species, amber, Bitterfeld.

КЛЮЧЕВЫЕ СЛОВА. Dytiscidae, Laccophilinae, новый род, новый вид, янтарь, Bitterfeld.

ABSTRACT. We provide the first report of a diving beetle (Coleoptera, Dytiscidae) from Saxonian (Bitterfeld) Amber. Based on a male specimen, collected in "Friedersdorfer Bernsteinschluff (Friedersdorf amber silt)" from the Cottbus Formation near Bitterfeld, Saxonia, Germany, †Electruphilus gen.n. †wendeli sp.n. is described. The new genus belongs to the subfamily Laccophilinae Gistel, 1848 and resembles species of Laccodytes Régimbart, 1895; however, all species of Laccodytes have the suture between elytron and epipleuron very well visible dorsally, which is not the case in $\dagger$ Electruphilus gen.n. Furthermore, the new genus is compared with the extant genera Australphilus Watts, 1978, Philaccolus Guignot, 1937 and Africophilus Guignot, 1948. We also provide a modified key to the Laccophilinae genera of the World, as we found minor errors or ambiguities in a recent key.

РЕЗЮМЕ. Представлены первые сведения о плавунцах (Coleoptera: Dytiscidae) из саксонского янтаря. $\dagger$ Electruphilus gen.n. $\dagger$ wendeli sp.n. описан по одному самцу, собранному в «Friedersdorfer Bernsteinschluff» из коттбусской свиты близ Биттерфельда, Саксония, Германия. Новый род относится к подсемейству Laccophilinae Gistel, 1848 и напоминает виды Laccodytes Régimbart, 1895; однако, у всех Laccodytes шов между надкрыльями и эпиплейроном хорошо виден дорсально, в отличие от $\dagger$ Electruphilus gen.n. Кроме того, новый род сравнивается с родами Australphilus Watts, 1978, Philaccolus
Guignot, 1937 и Africophilus Guignot, 1948. Предложен модифицированный ключ для родов Laccophilinae мировой фауны, так как были выявлены небольшие ошибки или неясности в последнем определителе.

\section{Introduction}

Diving beetles are rarely reported from amber. Described species include representatives of the subfamilies Agabinae (placed in: Hydrotrupes Sharp, 1882 Baltic amber; Holarctic), Copelatinae (Copelatus Erichson, 1832 - Baltic and Dominican amber; mostly Pantropical extant distribution), Dytiscinae $(\uparrow$ Ambarticus Yang et al., 2019 - Burmese amber), Hydroporinae (Hydroporus Clairville, 1806 - Baltic amber; Holarctic; Derovatellus Sharp, 1882 - Baltic amber; Pantropical extant distribution), and Laccophilinae ( $\mathrm{Ja}$ panolaccophilus Satô, 1972 — Baltic amber; Japan) [Klausnitzer, 2003; Miller, Balke, 2003; Balke et al., 2010; Gómez, Damgaard, 2014; Balke, Hendrich, 2019; Yang et al., 2019].

Here, we provide the first report of a diving beetle from Saxonian (Bitterfeld) amber. It is assumed that Baltic and Bitterfeld are distinct deposits [Wolfe et al., 2016], and possibly of the same age [Wolfe et al., 2016], but caution appears warranted as amber cannot be dated directly but only from the deposits it is being recovered from. A detailed discussion of Bitterfeld amber also in relation to Baltic amber was presented by Dunlop et al. [2018].

How to cite this article: Balke M., Toledo M., Gröhn C., Rappsilber I., Hendrich L. 2019. † Electruphilus wendeli gen.n., sp.n. — the first diving beetle recorded from Saxonian (Bitterfeld) Amber (Coleoptera: Dytiscidae: Laccophilinae) // Russian Entomol. J. Vol.28. No.4. P.350 -357. doi: 10.15298/rusentj.28.4.02 
The new species is a specimen well preserved, clearly belonging to the subfamily Laccophilinae Gistel, 1848 , the second known representative of this subfamily in amber. Extant Laccophilinae consist of two tribes with 14 genera and about 450 species, half of which belong to the large worldwide genus Laccophilus Leach [Nilsson, Hajek, 2019]. Roughly half of the Laccophilinae species are either strictly lotic, or to some degree associated with running waters, and the other half are related to lentic or stagnant waters. Japanolaccophilus beatificus Balke, Hendrich, 2019, is the first described fossil Laccophilinae from amber (Baltic amber). Remarkably, that genus has only one extant species, the running water Japanolaccophilus niponensis Kamiya,
1939 in Japan. The specimen described here is clearly different from $J$. beatificus and more than that, generic assignment was not without ambiguity.

\section{Materials and methods}

The beetles were studied with a Leica M205C stereo microscope at 10-160x. Photographs were taken with a digital imaging system composed of a Canon 5DS camera with Nikon bellows, and 5-20x ELWD Plan Apo objectives attached to a Mitutoyo focus lens. Image stacks were generated using the Stackmaster macro rail (Stonemaster), and images were then assembled with the computer software Helicon Focus 4.77TM.

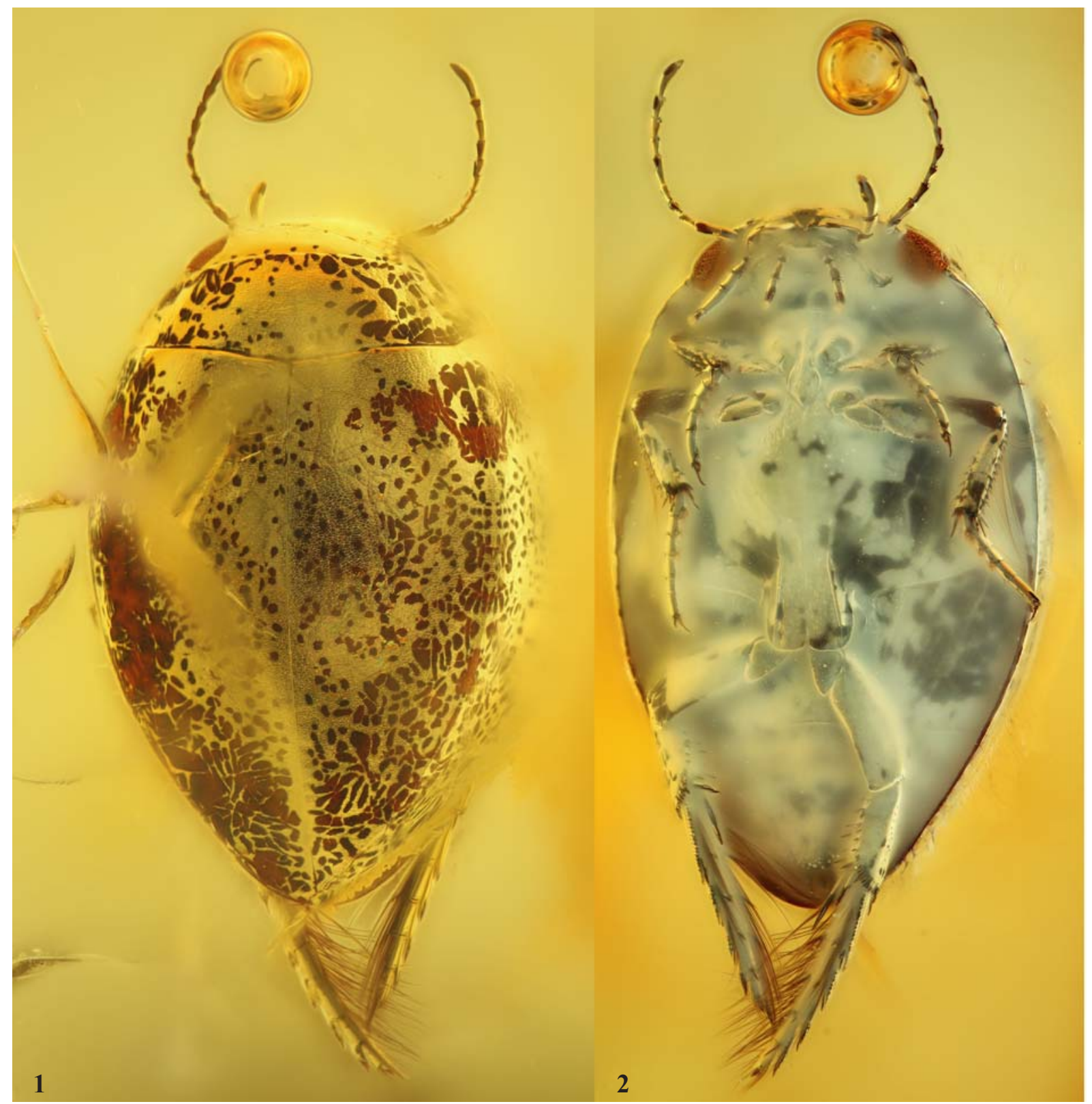

Figs 1-2. †Electruphilus wendeli gen.n., sp.n.: 1 - dorsal habitus; 2 - ventral habitus.

Pис. 1-2. †Electruphilus wendeli gen.n., sp.n.: 1 - сверху; 2 снизу. 


\section{Taxonomy}

The Bitterfeld specimen was assigned to the subfamily Laccophilinae: tribe Laccophilini due to the presence of distinctly lobed posterolateral margins of metatarsomeres I-IV, and less so V.

However, we were not able to unambiguously assign the Bitterfeld specimen to a known genus. Laccophilinae genera remain in need of comprehensive phylogenetic investigation to establish apomorphic characters for its genera. To date, the genera are usually diagnosed by a combination of characters, which individually might well occur in more than one genus. In fact, even charac- ters that were thought to diagnose Laccophilinae genera well have been shown to possibly be reversed in certain species (e.g. $>280$ species of Laccophilus assigned to that genus by bifid metatibial spurs, except for a New Guinea species [Balke et al., 1997]).

Family Dytiscidae Leach, 1815

Subfamily Laccophilinae Gistel, 1848

Tribe Laccophilini Gistel, 1848

$\uparrow$ Electruphilus Balke, Toledo et Hendrich, gen.n. Figs 1-8.

LIFE SCIENCE IDENTIFIER. Registered in Zoobank (www.zoobank.org) as urn:lsid:zoobank.org:act:4C37754E-F2B54D27-8D8A-F3340C151DF8.

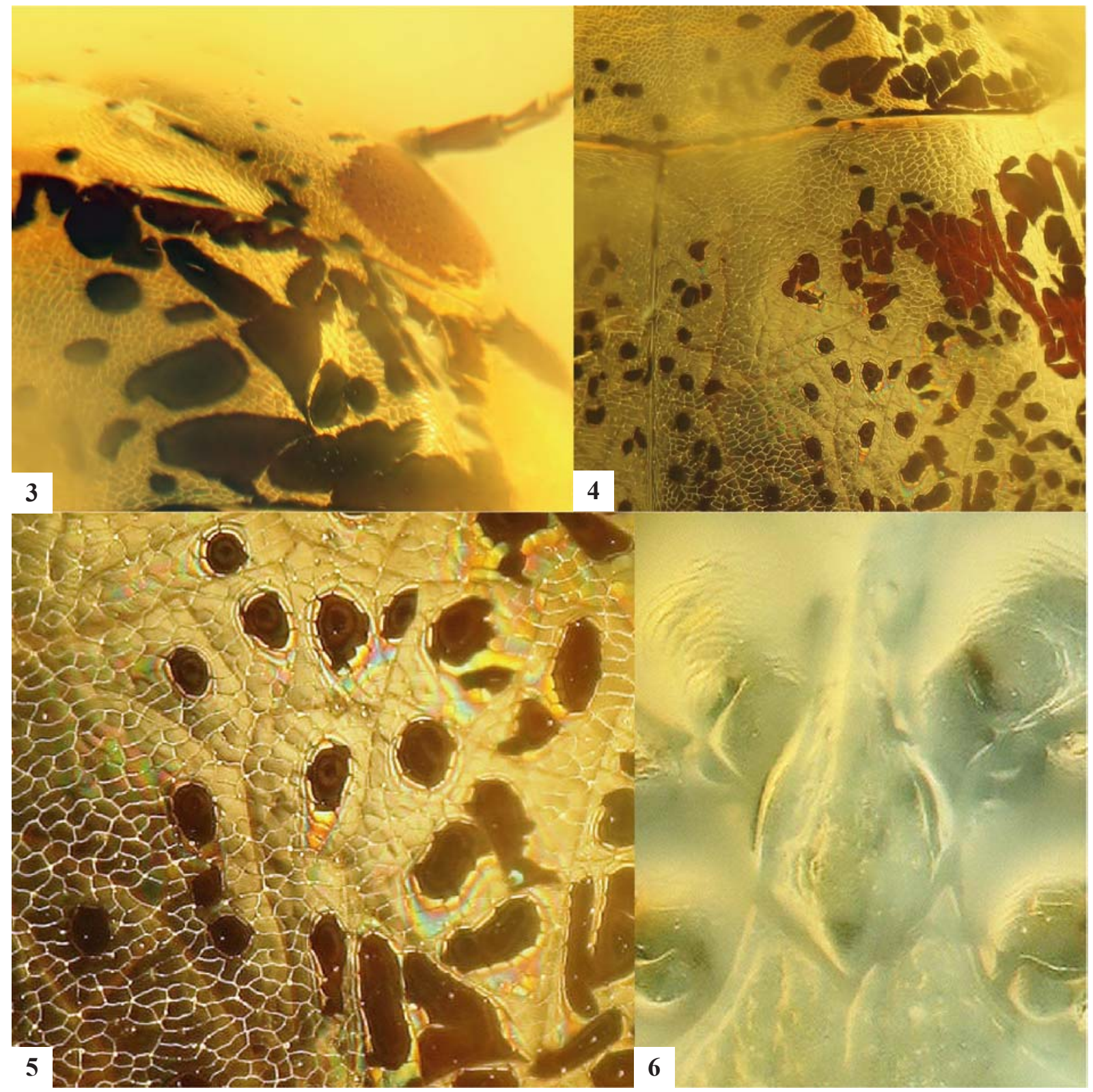

Figs 3-6. †Electruphilus wendeli gen.n., sp.n.: 3 - surface sculpture of head and anterior half of pronotum; 4 - surface sculpture of pronotal base and elytron; 5 - detail of surface sculpture of elytron; 6 - prosternal process and metasternal process.

Pис. 3-6. †Electruphilus wendeli gen.n., sp.n.: 3 - скульптура головы и передней части переднеспинки; 4 - скульптруа основания переднеспинки и надкрылий; 5 - детали скульптуры надкрылий; 6 - переднегрудной и заднегрудной отростки. 
TYPE SPECIES: $†$ Electruphilus wendeli Balke, Toledo, Hendrich, 2019, by present designation.

ETYMOLOGY. Derived from the Latin noun "electrum" meaning amber, and "-philus", here in reminiscence of the genus name Laccophilus, and other Laccophilinae genera with the same ending.

DIAGNOSIS. Small beetle, total length about 2.7 $\mathrm{mm}$, body oval, tear-shaped (Figs 1-2). Pronotum with hind margin almost straight, and hind angles broadly rounded; suture between elytron and epipleuron not visible dorsally; prosternal process broadened, somewhat deltoid, with rather obtuse tip, not exceeding in length the mesocoxal cavities (Figs 2, 6); metatibia with two simple spurs (not bifid); metacoxal lines straight, only slightly converging; hind margin of metacoxal processes truncate with lobes separated by a narrow but visible medial V-shaped notch (Figs 2,7). Fore and middle legs slender, with long tarsi. Metatibial spurs simple, not bifid apically; metatarsi distinctly but not broadly lobed. Male with pro- and mesotarsi not dilated, bearing 4 rows of stalked suction palettes (Fig. 8).

\section{$\dagger$ Electruphilus wendeli}

Balke, Toledo et Hendrich, sp.n.

Figs 1-8.

LIFE SCIENCE IDENTIFIER. Registered in Zoobank (www.zoobank.org) as urn:lsid:zoobank.org:act:9F3C976C-1B6A42D0-A6F3-CA4F1289623A.

TYPE LOCALITY. Germany, Saxonia-Anhalt, Bitterfeld.

AGE OF FOSSIL. "Bernsteinschluff" from the Cottbus Formation near Bitterfeld town, the sediments are possibly of the same age as Baltic amber, which is middle Eocene (Lutetian Stage; 41.3-47.8 Ma) [Wolfe et al., 2016].
MATERIAL. Holotype male. Bitterfeld amber (Coll. Goitzsche Bernstein $\mathrm{GmbH}$ ), red printed type label in the specimen box: "HOLOTYPE $\uparrow$ Electruphilus wendeli sp.n. Balke, Toledo \& Hendrich, des. 2019".

DESCRIPTION. Beetle oval, tear shaped (Figs 1-2); length of beetle without head about $2.5 \mathrm{~mm}$, with head about $2.7 \mathrm{~mm}$; greatest width about $1.7 \mathrm{~mm}$.

Colouration. Traces of colouration are visible on both dorsal and ventral surface (Figs 1-4). Colouration on head almost completely lost except for few small dark brown spots; pronotum with more numerous, rather uniformly dark brown fragments. Colouration on elytra better preserved, suggesting a pattern of dark marmorisation on a reddishbrown background; this is more evident on lateral side of left elytron and on latero-basal position of right elytron. Ventral surface mostly covered by glossy yellowish glaze, except for part of metaventrite and first ventrites of right side of abdomen, which are apparently dark brown; mesofemorae and mesotibiae dark brown.

Structures. Antenna filiform (Figs 1-2). Hind margin of pronotum almost straight, slightly concave in the middle; hind angles broadly rounded. Suture between elytron and epipleuron not visible dorsally, that means the elytron does not appear laterally bordered. Venter (Fig. 2): Prosternal process with rather obtuse tip exceeding to shortly before hind margins of procoxae, broadened, somewhat deltoid, with broad margin, ridge broadly rounded, not keeled (Figs 2-6). Prosternal ridge moderately sharp (Fig. 6). Metaventrite not well visible, lateral "wings" apparently narrow. No stridulatory files seem to occur on metacoxae. Metacoxal lines straight, only slightly converging, hind margin of metacoxal processes truncate with lobes separated by a narrow but visible medial V-shaped notch (Figs 2,7). Last sternite apparently not modified, apically rounded. Pro- (Fig. 8) and

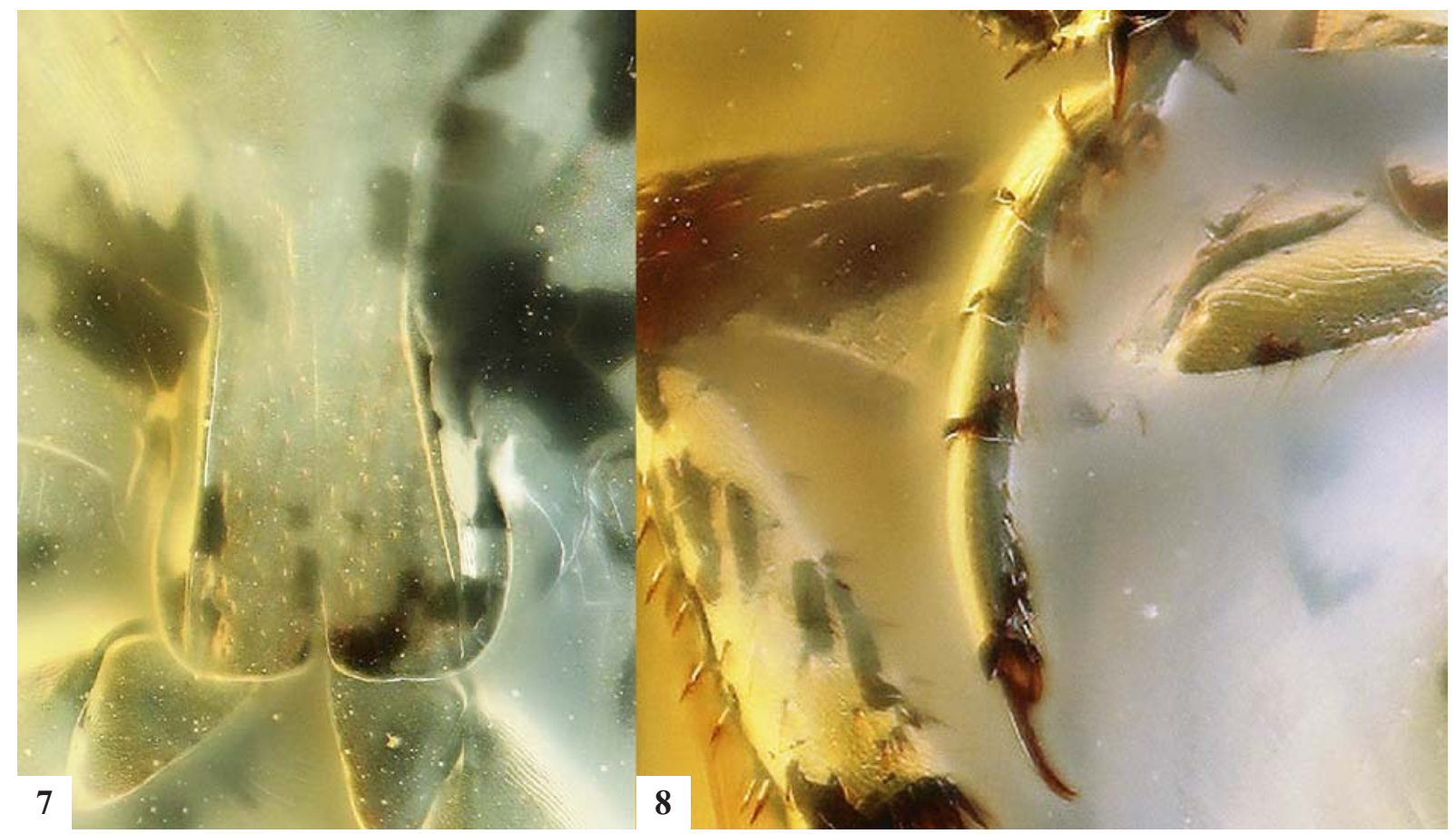

Figs 7-8. †Electruphilus wendeli gen.n., sp.n.: ; 7 - metacoxal process and metacoxal lines; 8 - detail of right protarsus and right mesotibia.

Рис. 7-8. †Electruphilus wendeli gen.n., sp.n.: ; 7 - отросток заднегруди и метакоксальные линии; 8 - строение правой передней лапки и средней голени. 
mesotarsi (Fig. 2) long and slender, not dilated, with tarsomeres I-IV almost of the same length and fifth slightly longer than third and fourth together. Pro- and mesotarsomeres altogether with 4 rows of small stalked suction palettes (two rows on I, one row on II and III), each row with no more than 2 or 3 visible palettes (Fig. 8); pro- and mesotarsal claws not modified and equal.

Surface sculpture. The dorsal surface shows irregular dark spots (Figs 1-3) which, on closer inspection, appear crater or pore like structures (Fig. 5) which are an artefact perhaps due to microbial activity during the earlier inclusion phase. Head with regular polygonal meshes, punctation not visible (Fig. 3). Pronotum with regular polygonal meshes, punctation not obvious, fine and sparse at most (Figs 1,4). Elytron with less regular and rather larger polygonal meshes and fine punctation (Figs 1, 4-5). Space between metacoxa with coarse and sparse punctures (Figs 2, 7). Metacoxa and abdominal sternites obscured. Surface of metasternal process (surface caudad of the prosternal process) appearing rough due to presence of larger dots / grooves. Metacoxa with diagonal lines. All femora and tibiae lacking very obvious punctation.

Genitalia. Genital capsule present, as inferred from the visibility of what we interpret as the tip of the median lobe (Fig. 2)
ETYMOLOGY. Named in honour of Andreas Wendel, a collector of Bitterfeld amber inclusions. He has made great efforts to establish the new amber mining from the Goitzsche lake, the origin of the beetles described here.

COMPARATIVE NOTES. As mentioned in the introduction, although likely contemporary, the Bitterfeld specimen is very different from the Baltic Japanolaccophilus beatificus Balke, Hendrich, 2019, at least at species level. The latter is larger, with different dorsal reticulation and dense punctuation on elytra, suture between elytron and epipleuron visible dorsally and fore and middle legs coarsely punctate on femora and tibiae. Unfortunately, the ventral features of $J$. beatificus are poorly visible and it is hard to make further comparisons with the better-preserved fossil from the Saxonian deposits. The only extant species of Japanolaccophilus, J. niponensis Kamiya, 1939, is also a larger beetle, with peculiar parallel metacoxal lines, coarsely punctuate fore and middle legs and a visible elytron-epipleuron suture in dorsal sight.

Compared to other known Laccophilini genera, in terms of size, body shape and long and slender pro- and mesotarsi, the Bitterfeld specimen resembles species of the Neotropical Laccodytes Régimbart, 1895 (Figs 9-11), a very diverse genus in terms of morphological structures [Toledo et al., 2010] that are usually being used to diagnose genera, such as shape and
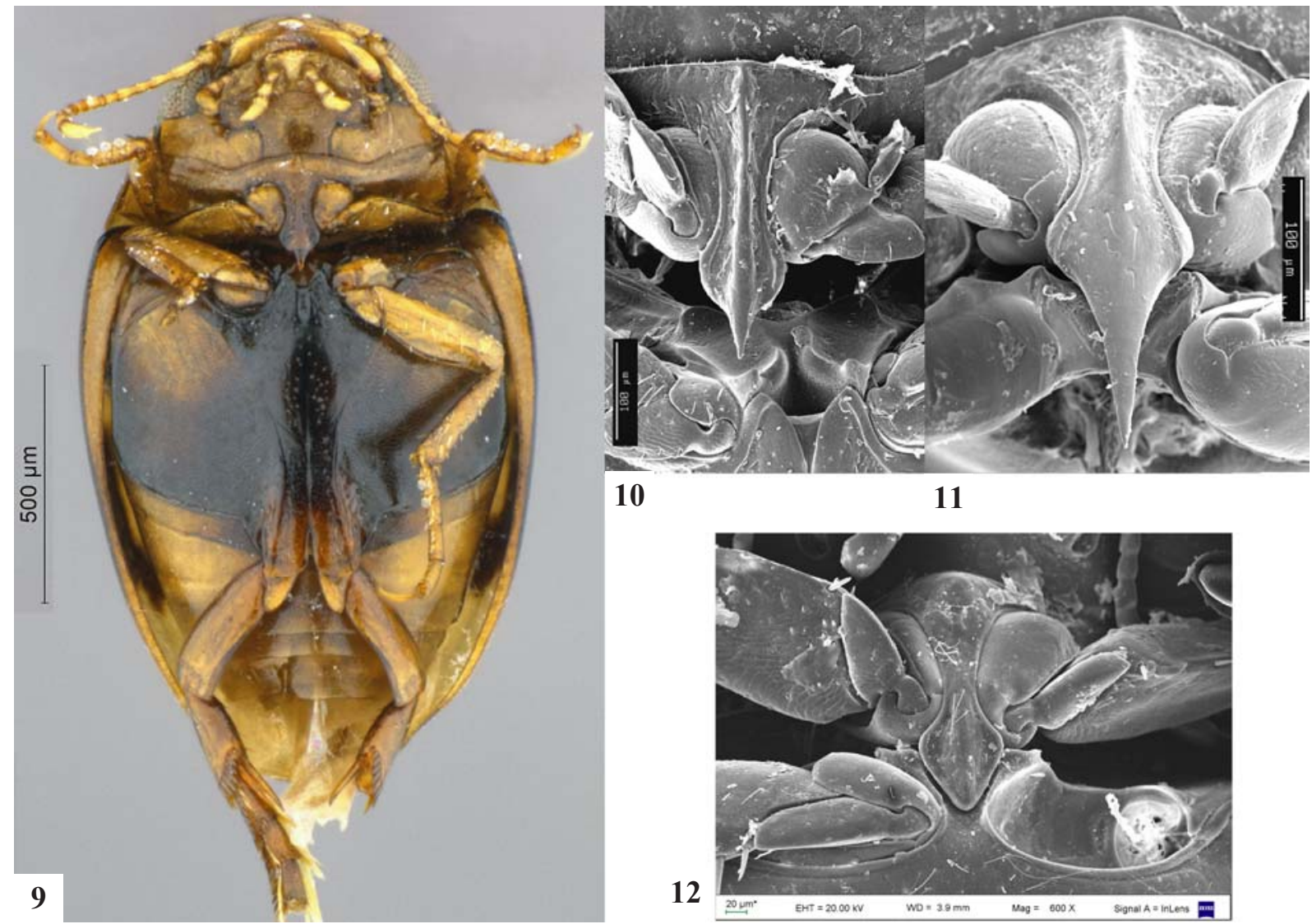

10

11

12

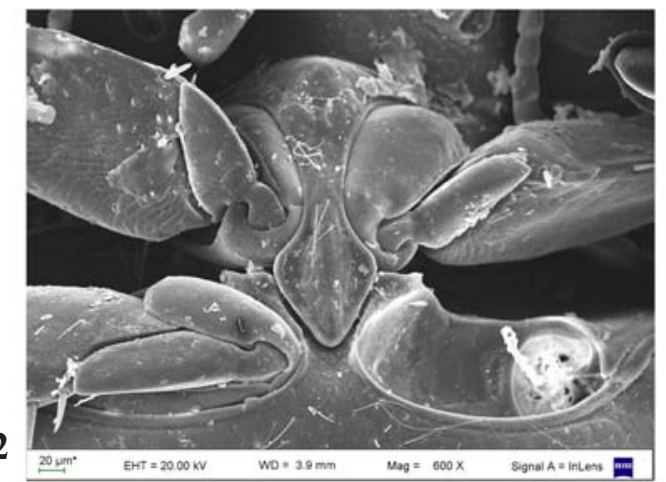

Figs 9-12. Laccodytes spp.: 9 - L. takutuanus Toledo et al., 2010; 10 - L. neblinae Toledo et al., 2010; 11 - L. apalodes Guignot, 1955; 12 - Laccomimus bordoni Toledo, Michat, 2015; 9 - male, ventral view (photo by Cesar Benetti); 10-12 - SEM photo of prosternal process [from Toledo, Michat, 2015].

Pис. 9-12. Laccodytes spp.: 9 - L. takutuanus Toledo et al., 2010; $10-$ L. neblinae Toledo et al., 2010; 11 - L. apalodes Guignot, 1955; 12 — Laccomimus bordoni Toledo, Michat, 2015; 9 - самец, снизу (photo by Cesar Benetti); 10-12 — SEM фотография отростка переднегруди [по Toledo, Michat, 2015]. 
length of prosternal process, shape of hind angle of pronotum, curvature of middle of pronotal base, and shape of hind margin of metacoxal processes [Toledo, Michat, 2015]. However, all species of Laccodytes have the suture between elytron and epipleuron very well visible dorsally and this is not the case in the amber inclusion. All Laccodytes, hence, have a different elytral sculpture, a remarkably different shape of prosternal process as well, though variable between the species of this genus (Figs 9-11) and, only one pair of stalked suction palettes on the first segment of male pro- and mesotarsi. The shape of the metacoxal process in the present fossil resembles the structure occurring in some species of Laccodytes, though the slightly stronger punctuation between the metacoxal lines do more reflect the situation in the Australian genus Australphilus Watts, 1978 (Figs 14, 16), as well as the rough surface of metasternal process, although it seems that the rest of metaventrite is smooth, being the contrary of Australphilus. The broad, short and broadly margined prosternal process of the new genus looks rather similar to that of Laccomimus Toledo, Michat, 2015 or Laccosternus Brancucci, 1983, but in these genera this structure is somewhat arrow-shaped (Fig. 12), whilst in $\dagger$ Electruphilus gen. n. it is more tear-shaped (Fig. 6) whereas, regarding other characters, the new genus is obviously poorly related with Laccomimus and Laccosternus.

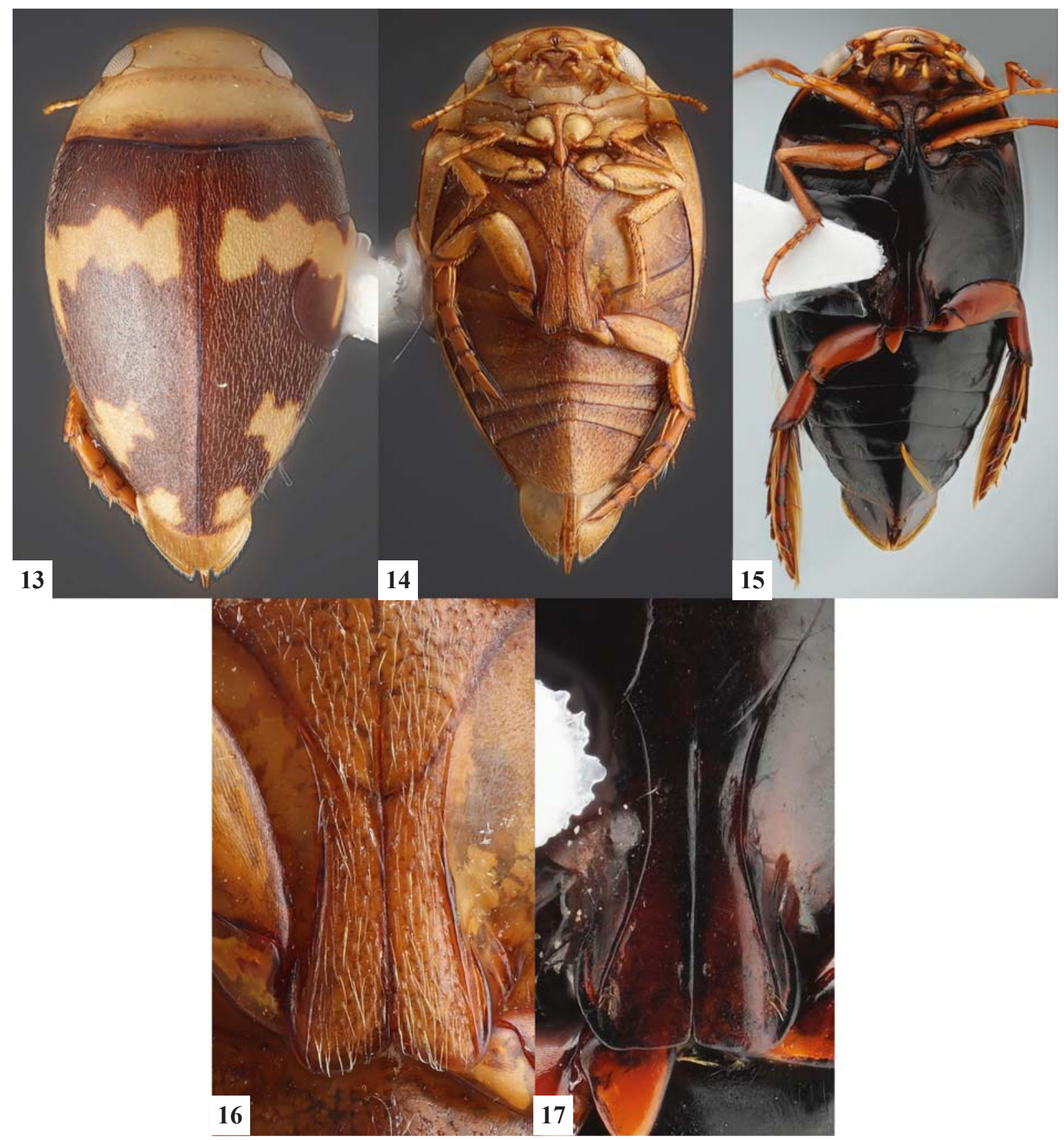

Figs 13-17. Laccophilinae: 13-14, 16 - Australphilus saltus Watts, 1978; 15, 17 - Philaccolilus ameliae Balke et al., 2000; 13 dorsal side; 14-15 - ventral side; 16-17 - metacoxae and metacoxal lines.

Pис. 13-17. Laccophilinae: 13-14, 16 - Australphilus saltus Watts, 1978; 15, 17 - Philaccolilus ameliae Balke et al., 2000; 13 сверху; 14-15 - снизу; 16-17 - задние тазики и метакоксальная линия. 
† Laccophilus strigatus (Schlechtendal, 1894), originally described in the genus Palaeogyrinus Schlechtendal, 1894 from Miocene deposits of Germany (see Galewski, Głazek, 1978; Prokin, Dong, 2010; Nilsson, Hajek, 2019) differs from other Laccophilinae by sulcate elytra and does not share close relationships with $\dagger$ Electruphilus gen.n.

TAXONOMY AND BIOGEOGRAPHY. The lack of a phylogenetic inference for Laccophilinae does not permit an unambiguous placement of the Saxonian amber specimen and, thus, it is not possible to provide a formal biogeographic analysis here. Likely $\dagger$ Electruphilus gen.n. represents an ancient lineage of Laccophilini within which it seems rather difficult to find close affinities with extant genera. We merely point out that there is a possibility that $\dagger$ Electruphilus gen.n. and Laccodytes might be closely related or sister taxa. Such a case of a Baltic amber fossil († Euroleptochromus Jałoszyński, 2012) and an extant Neotropical sister group was suggested by Jałoszyński [2012] in a clade of Coleoptera, Staphylinidae, Scydmaeninae. Pütz et al. [2004] discussed a similar scenario for an extinct Baltic Coleoptera: Limnichidae $(\dagger$ Palaeoersachus Pütz et al., 2004). Other such cases are summarized in the very detailed review of Eocene amber beetles by Alekseev [2017]. One possible explanation for such a distribution pattern might be a range expansion via trans Beringian dispersal e.g. in the Eocene, before the onset of cooling of the higher latitudes of the northern hemisphere towards the Oligocene (see Pütz et al. [2004] and references therein; as well as Alekseev [2017]).

\section{ANNOTATED KEY TO LACCOPHILINAE GENERA}

(based on Toledo and Michat [2015] as modified by Balke and Hendrich [2019]) (annotations, additions and corrections underlined).

NOTE: The well illustrated key by Miller and Bergsten [2016] relies basically on the same characters as Toledo and Michat [2015]

1. Metatibiae with a single apical spur; antennal segments enlarged and flattened in male. Neotropical

Napodytes

- Metatibiae with 2 apical spurs; antennal segments never enlarged or flattened in male

2. Suture between elytron and epipleuron very well visible dorsally (= "lateral sides bordered": in dorsal view elytra visibly outlined by a fine border along outer lateral side)

- Suture between elytron and epipleuron not visible dorsally (= "lateral sides not bordered": in dorsal view the elytra do not appear to be bordered) or suture visible only apically (in New Guinea genus Philaccolilus) ............ 6

3. Hind angles of pronotum rounded; prosternal process shorter, not extending beyond mesacoxae (Figs 9-10). ............. 4

- Hind angles of pronotum extending posteriorly into acuminate spine; prosternal process long, extending beyond mesocoxae (Fig. 11).

4. Base of pronotum projecting hindwards in a distinct angle at middle; pro and mesotibia and femur at most with fine punctation. Neotropical ....

Laccodytes phalacroides-group

- Base of pronotum straight or almost so; fore and middle tibia and femur with dense, coarse punctation. Palearctic Japanolaccophilus

5. Prosternal process trifid; posterolateral lobes of metatarsi very short, almost lacking; apex of elytra rounded. Afrotropical and Oriental

Neptosternus

- Prosternal process simple (Fig. 11); posterolateral lobes of metatarsi longer, well developed; apex of elytra truncated. Neotropical

Laccodytes apalodes-group
6. Metatibial spurs bifid apically [except in L. bapak Balke, Larson, Hendrich, 1997 from Papua New Guinea]. Worldwide ........................................................ Laccophilus

- Metatibial spurs simple, apically acute. ........................ 7

7. Base of pronotum projecting hindwards in a distinct angle at middle. .................................................................... 8

- Base of pronotum straight or almost so. ................... 11

8. Prosternal process laterally compressed behind procoxae Prosternal process fairly broad behind procoxae ............ 10

9. Length not exceeding $5 \mathrm{~mm}$; pro- and mesofemora and tibiae densely punctate; prosternal process markedly carinate. Tibet Laccoporus

- Length exceeding $5 \mathrm{~mm}$; pro- and mesofemora and tibiae never densely punctate; prosternal process slightly carinate. Africa

Philodytes

10. Mesotibial spurs not longer than segments 1-2 of mesotarsi combined; elytra covered by numerous, more or less impressed punctures. Oriental

Laccosternus

- Mesotibial spurs longer than segments 1-4 of mesotarsi combined; elytra lacking punctures, at most bearing very few, small, hardly visible punctures. Neotropical and SE Nearctic

Laccomimus

11. Reticulation on elytra consisting of longitudinal or broad polygonal meshes; metacoxal lines fairly parallel. Afrotropical Africophilus

- Reticulation on elytra consisting of small, transversal meshes; metacoxal lines more or less convergent anteriorly

12. Space between metacoxal lines with numerous coarse setiferous punctures; metacoxal processes, distally bilobed. Australia ........... Australphilus (Figs 13-14, 16)

- Space between metacoxal lines not with such setiferous punctures; metacoxal processes distally not bilobed ... 13

13. Metacoxal lines slightly converging (Fig. 2) .................. $\uparrow$ Electruphilus gen.n. (Figs 1-8)

- Metacoxal lines strongly converging (Figs 15, 17)... 14

14. Metacoxa with stridulatory file; posterolatral lobes of metatarsi short; ventrite 6 in females rounded apically. Afrotropical.

Philaccolus

- Metacoxa lacking stridulatory file; posterolateral lobes of metatarsi very long; ventrite 6 in females with an apical lobe, more or less developed. Papua New Guinea .........

Philaccolilus (Figs 15, 17)

Acknowledgements. Michael Balke acknowledges support from the EU SYNTHESYS program, projects FR-TAF6972 and GB-TAF-6776 which supported this research during visits to NHM and MNHN in 2017, as well as DFG grant Ba2152/241-1. We thank Cesar Benetti for sharing his unpublished photo of Laccodytes takutuanus Toledo, Spangler et Balke, 2010, and one anonymous reviewer for valuable suggestions.

\section{References}

Alekseev V.I. 2017. Coleoptera from the middle-upper Eocene European ambers: generic composition, zoogeography and climatic implications // Zootaxa. Vol.4290. No.3. P.401-443.

Balke M., Hendrich L. 2019. †Japanolaccophilus beatificus sp. nov. from Baltic Amber and a key to the Laccophilinae genera of the World (Coleoptera: Laccophilinae) // Zootaxa. Vol.4567. No.1. P.176-182.

Balke M., Larson D.J., Hendrich L. 1997. A review of the New Guinea species of Laccophilus Leach 1815 with notes on region- 
al melanism (Coleoptera Dytiscidae)// Tropical Zoology. Vol.10. No.2. P.295-320.

Balke M., Beigel A., Hendrich L. 2010. Hydroporus carstengroehni sp.n. und zwei unbestimmte Hydroporinae aus dem baltischen Bernstein (Dytiscidae: Hydroporinae) // Nachrichtenblatt der bayerischen Entomologen. Bd.59. S.2-9.

Dunlop J.A., Kotthoff U., Hammel J.U., Ahrens J., Harms D. 2018. Arachnids in Bitterfeld amber: A unique fauna of fossils from the heart of Europe or simply old friends? // Evolutionary Systematics. Vol.2. No.1. P.31-44.

Galewski K., Głazek J. 1977. Upper Miocene Dytiscidae (Coleoptera) from Przeworno (Lower Silesia) and the Problem of Dytiscidae Evolution // Bulletin de l'Académie polonaise des sciences. Série des sciences biologiques. Vol.25. P.781-789.

Gómez R.A., Damgaard A.L. 2014. A rare diving beetle from Baltic Amber: Hydrotrupes prometheus new species reveals former widespread distribution of the genus (Coleoptera, Dytiscidae) // Journal of Palaeontology. Vol.88. No.4. P.814-822.

Jałoszyński P. 2012. Description of Euroleptochromus gen. n. (Coleoptera, Staphylinidae, Scydmaeninae) from Baltic amber, with discussion of biogeography and mouthpart evolution within Clidicini // Systematic Entomology. Vol.37. No.2. P.346-359.

Klausnitzer B. 2003. Käferlarven (Insecta: Coleoptera) in Baltischen Bernstein — Möglichkeiten und Grenzen der Bestimmung // Entomologische Abhandlungen. Vol.61. No. 1. P.103108.

Miller K.B., Balke M. 2003. The unusual occurrence of water beetles in amber: Copelatus aphroditae Balke n. sp. and C. predaveterus Miller n. sp. (Coleoptera: Dytiscidae: Copelatinae) // Pro- ceedings of the Entomological Society of Washington. Vol.105. P.809-815.

Miller K.B., Bergsten J. 2016. Diving beetles of the world. Systematics and biology of the Dytiscidae. Baltimore: Johns Hopkins University Press. 320 pp.

Nilsson A.N., Hájek J. 2019. A world catalogue of the family Dytiscidae (Coleoptera, Adephaga). 307 pp. Internet version 1.I.2019. Available from: http://www.waterbeetles.eu.

Prokin A.A., Dong R. 2010. New mesozoic diving beetles (Coleoptera, Dytiscidae) from China // Paleontological Journal. Vol.44. No.5. P.526-533.

Pütz A., Hernando C., Ribera I. 2004. A new genus of Limnichidae (Coleoptera) from Baltic amber // Insect Systematics \& Evolution. Vol.35. No.3. P.329-334.

Toledo M., Michat M.C. 2015. Description of Laccomimus gen. n. and eleven new species from the Neotropical region (Coleoptera, Dytiscidae, Laccophilinae) // Zootaxa. Vol.3990. No.3. P.301354. doi.org/10.11646/zootaxa.3990.3.1.

Toledo M., Spangler P.J., Balke M. 2010. Taxonomic revision of the Neotropical diving beetle genus Laccodytes Régimbart, 1895 (Coleoptera: Dytiscidae) // Zootaxa. Vol. 2347. No.1. P.37-58. Wolfe A.P., McKellar R.C., Tappert R., Sodhi R.N., Muehlenbachs K. 2016. Bitterfeld amber is not Baltic amber: Three geochemical tests and further constraints on the botanical affinities of succinite // Review of Palaeobotany and Palynology. Vol.225. P.21-32.

Yang Q., Chen Z.-Y., Jia F.J. 2019. Ambarticus myanmaricus gen. et sp. nov., the first diving beetle from mid-Cretaceous amber of northern Myanmar (Coleoptera, Dytiscidae, Dytiscinae) // Cretaceous Research. Vol.102. P.1-6. 